\title{
INVENTARISASI HAMA AKIBAT PERLAKUAN MACAM JARAK TANAM TERHADAP TIGA VARIETAS KEDELAI Glycine $\max (L)$ Merill
}

\author{
Lulus Fitriyani*, Sartono Joko**, Sumarmi** \\ *Fakultas Pertanian, Universitas Slamet Riyadi, Surakarta, E-mail: lulusfitriyani98@ gmail.com \\ **Fakultas Pertanian, Universitas Slamet Riyadi, Surakarta
}

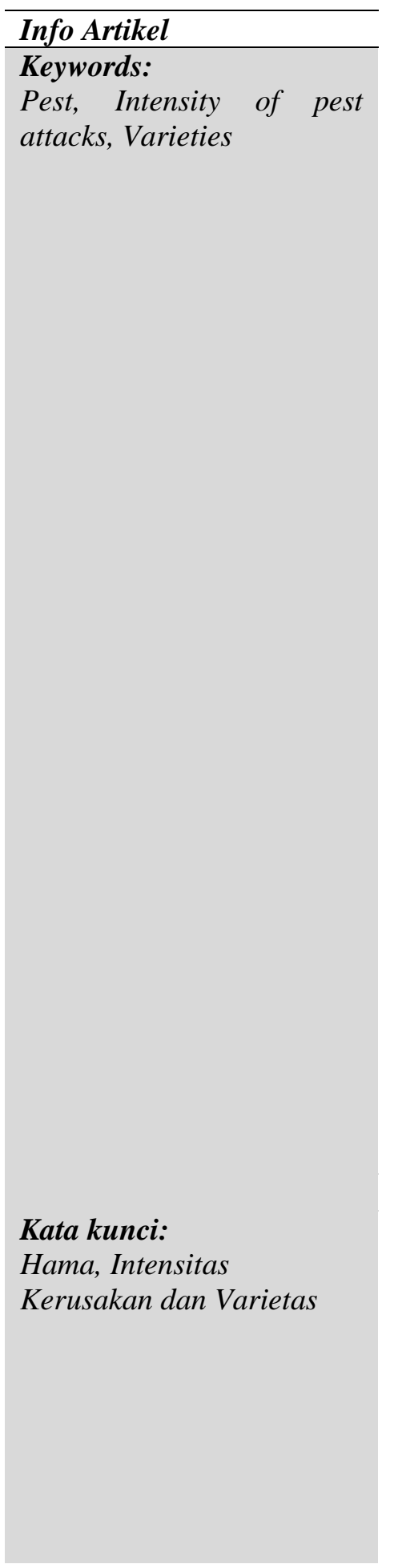

\begin{abstract}
The purpose of this research was to investory the types of pest from the symptoms and signs of damage from variouse types of planting distance on there of soybean. This research was conducted in April 2019 until Juli 2019, a research site in Gatak Hamlet, Senting Village, Sambi Subdistrict, Boyolalai Regency with Grumosol soil types and altitude \pm 200 meters above sea level. This study uses a Complete Randomized Block Design (CRBD) arranged in Split Plots consisting of 2 treatment factors, namely the type of soybean $(V)$ as the main plot an planting distance $(J)$ as a sub plot, so 9 treatment combinations were obtained and each was repeated 3 times. The results showed (1) The types of pest found at the time of the study were green grasshopper pest with the highest attack intensity in the treatment Grobogan of varieties with planting distance $30 \mathrm{~cm} \times 40 \mathrm{~cm}$ (V1J3), wich was an average of 29.79\%. Caterpillar leaves pest with the highest attack intensity in the treatment Grobogan of varieties with planting distance $30 \mathrm{~cm} \times 40 \mathrm{~cm}$ (V1J3), wich was an average Of $30 \%$, Anjasmoro of varieties with planting distance $30 \mathrm{~cm} \times 20 \mathrm{~cm}$ (V2J1), wich was an average of 30\%, Grobogan of varieties with planting distance $30 \mathrm{~cm} \times 30 \mathrm{~cm}$ (V2J2), wich was an average of $30 \%$. Pod borer pest with the highest attack intensity in the treatment Anjasmoro of varieties with planting distance $30 \mathrm{~cm} \times 30 \mathrm{~cm}$ wich was an average of 29,97\% (2) The provision of spasing $30 \mathrm{~cm} \times 40 \mathrm{~cm}$ does significantly affect the intensity of pest attacks on three types of soybean (3) Grobogan of varieties and spasing $30 \mathrm{~cm} \times 40 \mathrm{~cm}$ (V1J3) had the highest the number of pods yields which was an average of 88 pods, the pod weight $60,11 \mathrm{gram} / \mathrm{m}^{2}$, and yield of seed weight $16,95 \mathrm{gram} / \mathrm{m}^{2}$. And the highest the number of seeds yields had the highest on Grobogan of varieties and spasing $30 \mathrm{~cm} \times 40 \mathrm{~cm}$ which was an average 143,56 seeds, and on Grobogan varieties with planting distance $30 \mathrm{~cm} \times 30 \mathrm{~cm}$ of was an average $13,60 \mathrm{gram} / \mathrm{m}^{2}$.
\end{abstract}

\footnotetext{
Abstrak

Tujuan penelitian ini untuk menginventarisasi jenis-jenis hama dari gejala dan tanda kerusakan dari perlakuan macam jarak tanam terhadap tiga varietas kedelai. Penelitian ini telah dilaksanakan pada 14 April 2019 sampai dengan bulan 13 Juli 2019, tempat penelitian di Dusun Gatak, Desa Senting, Kecamatan Sambi, Kabupaten Boyolali dengan jenis tanah Grumosol dan ketinggian tempat \pm 200 meter dpl. Penelitian ini menggunakan Rancangan Acak Lengkap (RAKL) yang disusun secara Split Plot terdiri dari 2 faktor perlakuan yaitu macam varietas (V) sebagai main plot (petak utama) dan jarak tanam (J) sebagai sub plot (anak petak),
} 
sehingga diperoleh 9 kombinasi perlakuan dan masing-masing diulang 3 kali. Hasil Penelitian menunjukkan (1) Jenis hama yang ditemukan pada saat penelitian yaitu hama belalang hijau dengan intensitas serangan tertinggi pada perlakuan varietas kedelai Grobogan dengan jarak tanam $30 \mathrm{~cm}$ x $40 \mathrm{~cm}(\mathrm{~V} 1 \mathrm{~J} 3)$ yaitu dengan rata-rata $29,79 \%$, hama ulat daun dengan intensitas serangan hama tertinggi pada perlakuan varietas Grobogan dengan jarak tanam 30 $\mathrm{cm} \times 40 \mathrm{~cm}$ (V1J3) dengan rata-rata 30\%, pada varietas Anjasmoro dengan jarak tanam $30 \mathrm{~cm} \times 20 \mathrm{~cm}$ (V2J1) dengan rata-rata 30\% serta pada varietas Anjasmoro dengan jarak tanam $30 \mathrm{~cm} \times 30 \mathrm{~cm}$ (V2J2) dengan rata-rata 30\%. Hama penggerek polong dengan intensitas serangan tertinggi pada perlakuan varietas Anjasmoro jarak tanam $30 \mathrm{~cm}$ x $30 \mathrm{~cm}$ (V2J2) dengan rata-rata $29,97 \%$. (2) Penggunaan jarak tanam $30 \mathrm{~cm}$ x $40 \mathrm{~cm}$ berpengaruh nyata terhadap intensitas serangan hama pada tiga macam varietas kedelai (3). Varietas Grobogan dan perlakuan jarak tanam $30 \mathrm{~cm}$ x $40 \mathrm{~cm}$ (V1J3) memiliki hasil jumlah polong yaitu dengan rata-rata 88 buah, berat polong $60.11 \mathrm{gram} / \mathrm{m}^{2}$ dan berat biji $16.95 \mathrm{gram} / \mathrm{m}^{2}$. Jumlah biji tertinggi pada varietas Grobogan dengan jarak tanam $30 \mathrm{~cm}$ x $40 \mathrm{~cm}$ dengan rata-rata 143,56 , and varietas Grobogan dan jarak tanam $30 \mathrm{~cm} \times 30 \mathrm{~cm}$ dengan rata-rata $13,60 \mathrm{gram} / \mathrm{m}^{2}$.

\section{PENDAHULUAN}

Tanaman Kedelai Glycine $\max (L)$ Merill merupakan salah satu tanaman penting setelah padi dan jagung. Tanaman ini merupakan bahan makanan yang mempunyai kandungan nilai gizi yang cukup tinggi bila dibandingkan bahan makanan lainnya. Diantara tanaman kacang-kacangan lainnya kedelai merupakan sumber protein, lemak, vitamin, mineral dan serat yang paling baik (Cahyadi, 2009). Untuk mencapai hasil yang tinggi sangat ditentukan oleh potensi genetiknya sehingga varietas berperan penting dalam produksi kedelai. Hasil produksi dipengaruhi oleh interaksi antara faktor genetik dengan pengelolaan kondisi lingkungan. Bila pengelolaan lingkungan tidak dilakukan dengan baik, potensi hasil yang tinggi dari varietas unggul tersebut tidak dapat tercapai (Adisarwanto 2006).

Beberapa varietas unggul tanaman kedelai diantaranya varietas Grobogan, Anjasmoro, dan Malika. Varietas Grobogan merupakan varietas berumur genjah karena dapat dipanen pada umur $(<80$ hari) yaitu sekitar 76 hari setelah tanam. Varietas Anjasmoro dan Varietas Malika merupakan varietas berumur sedang karena dapat dipanen pada umur (sekitar >80 hari) (Susanto dan N. Nugrahaeni. 2016). Penggunaan jarak tanam berkaitan erat dengan kerapatan tanaman, jika tanaman terlalu rapat penyinaran matahari tidak merata. Sehingga kondisi di sekitar tanaman menjadi lebih lembab. Kondisi tersebut mendukung perkembangbiakan hama dan timbulnya berbagai penyakit. Diduga dengan pengaturan jarak tanam tertentu dapat menciptakan mikrohabitat sekitar tanaman sehingga diharapkan dapat menekan perkembangan hama dan pathogen. Tetapi dapat juga merugikan perkembangbiakan hama tertentu (Untung, 2013).

Tujuan penelitian ini untuk menginventarisasi hama yang menyerang tiga varietas tanaman kedelai serta tingkat kerusakannya akibat perlakuan berbagai macam jarak tanam. Diduga dengan menggunakan jarak tanam 30 x $40 \mathrm{~cm}$ pada varietas Anjasmoro tingkat serangan hamanya rendah dan dapat memberikan hasil yang optimal.

\section{BAHAN DAN METODE}

Dalam penelitian ini menggunakan Rancangan Acak Kelompok Lengkap ( RAKL ) yang disusun secara Split Plot yang terdiri dari 2 faktor perlakuan yaitu dengan 3 macam jarak tanam yang 
digunakan sebagai sub plot (anak petak) dan 3 macam varietas kedelai sebagai main plot (petak utama), sehingga diperoleh 9 kombinasi perlakuan dan diulang 3 kali.

Bahan yang digunakan antara lain : benih kedelai Varietas Grobogan, Varietas Anjasmoro, Dan Varietas Malika. Pupuk yang digunakan yaitu pupuk Urea, SP36, dan KCL sesuai dengan rekomendasi. Alat yang digunakan yaitu : cangkul, sabit, dan tugal, penggaris, alat tulis, meteran, gelas ukur, dan timbangan. Penelitian telah dilaksanakan pada 14 April 2019 sampai dengan 13 Juli 2019, bertempat di Dusun Gatak, Desa Senting, Kecamatan Sambi, Kabupaten Boyolali dengan ketinggian tempat $200 \mathrm{mdpl}$ dan jenis tanahnya Grumosol.

Pengamatan dilakukan sejak tanaman berumur 30 hari setelah tanam dengan interval setiap satu minggu sekali. Pengambilan tanaman sampel disesuaikan dengan jarak tanam, pada jarak tanam $30 \mathrm{~cm}$ x $20 \mathrm{~cm}$ pengamatan dilakukan pada 5 tanaman sampel, pada jarak tanam $30 \mathrm{~cm}$ x $30 \mathrm{~cm}$ pengamatan dilakukan pada 4 tanaman sampel, dan pada jarak tanam $30 \mathrm{~cm}$ x $40 \mathrm{~cm}$ pengamatan dilakukan pada 3 tanaman sampel, yang di ambil secara diagonal disetiap petaknya. Dengan parameter antara lain : jenis hama yang menyerang, intensitas kerusakan, jumlah polong kedelai basah pertanaman, berat polong kedelai basah pertanaman (gram), jumlah biji kedelai kering per tanaman, berat biji kedelai kering per tanaman (gram), berat 100 biji kedelai (gram)

\section{HASIL DAN PEMBAHASAN}

Hasil pengamatan yang telah dilakukan selama 10 minggu dengan intensitas pengamatan 1 minggu sekali di lahan, ada beberapa jenis hama yang telah menyerang antara lain hama belalang hijau, ulat daun, ulat grayak dan penggerek polong. Data macam hama dapat dilihat pada tabel 1.

Tabel 1. Macam hama

\begin{tabular}{ccc}
\hline Jenis Hama & Nama Latin & Mulai Serangan Pengamatan Ke \\
\hline Belalang Hijau & Oxya chinensis & 1 \\
Ulat Daun & Lamprosema indica $F$ & 3 \\
Ulat Garayak & Spodoptera litura & 5 \\
Penggerek Polong & Etiella zickenella Treit & 6 \\
\hline
\end{tabular}

Keterangan : Data awal muncul serangan hama dari awal pengamatan sampai akhir pengamatan.

Data awal kemunculan hama menunjukkan serangan hama belalang terjadi pada pengamatan pertama saat tanaman berumur 5 minggu setelah tanam. Hal ini dikarenakan hama belalang dapat di temui dari fase vegetatif sampai generatif. Belalang memakan daun tanaman kedelai di bagian tepi daun sehingga mengurangi luas permukaan daun yang mengakibatkan daun menjadi berlubang. Gejalannya kadang-kadang sulit di bedakan dengan serangan ulat daun, lubang akibat serangan belalang tepinya bergerigi dan kasar, sedangkan hama ulat daun bekas gigitannya lebih halus. Meskipun kerusakan daun tidak serius akan tetapi kerusakan ini mengakibatkan pengaruh terhadap proses fotosintesis sehingga berkurangnya produktifitas tanaman kedelai yang terserang.

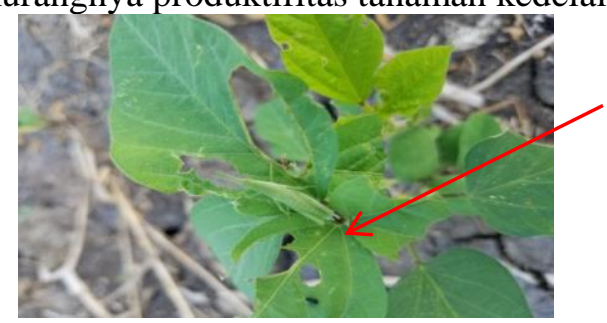

(a) Gejala serangan hama belalang

Ulat daun muncul pada pengamatan ke-3 saat tanaman berumur 7 minggu setelah tanam (MST). Gejala yang ditimbulkan ulat daun yaitu adanya lubang bekas gigitan ulat yang halus yang berupa lubang-lubang kecil berbentuk bulat. Jika serangan parah daun yang awalnya memiliki lubang sedikit maka menjadi semakin melebar. 


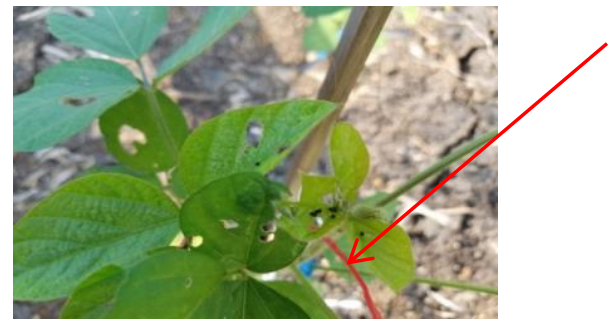

(b) Gejala serangan ulat daun

Ulat grayak muncul pada pengamatan ke-5 saat tanaman berumur 9 (MST). Gejala serangan yang ditimbulkan adanya lubang-lubang daun yang lebih besar yang tidak menentu. Jika serangannya semakin parah hama ini merusak daun dan meninggalkan bagian epidermis dan bagian tulang daun. Hama ini biasanya menyerang tanaman saat malam hari sehingga ketika sudah pagi daun-daun yang terserang sudah habis. Saat matahari mulai terbit hama ini bersembunyi di dalam tanah.

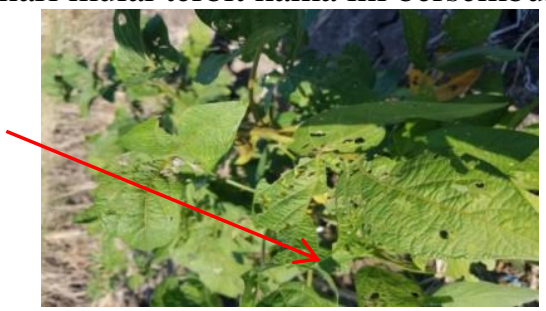

(c) Gejala serangan ulat grayak

Penggerek polong muncul pada pengamatan ke 6 saat tanaman telah berumur 10 MST. Gejala yang ditemukan terdapat bekas gigitan berwarna cokelat dibagian kulit kedelai dan pada akhirnya akan berlubang. Hama tersebut mengambil cairan yang ada pada biji-biji yang masih muda sehingga menyebabkan polong hampa.

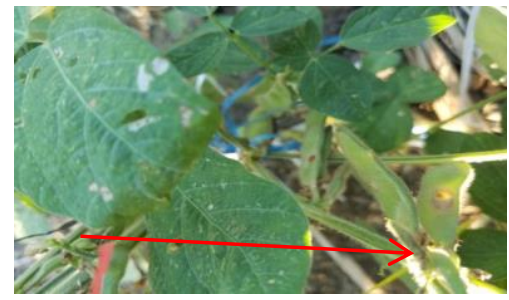

(d) Gejala serangan penggerek polong

Tabel 2. Intensitas kerusakan hama

\begin{tabular}{ccccc}
\hline \multirow{2}{*}{ Perlakuan } & \multicolumn{4}{c}{ Macam Hama \& Intensitas Kerusakan } \\
\cline { 2 - 5 } & Belalang & Ulat Daun & Ulat Grayak & Penggerek Polong \\
\hline V1J1 & $25.09 \mathrm{a}$ & $29.55 \mathrm{a}$ & $31.49 \mathrm{a}$ & $18.11 \mathrm{a}$ \\
V1J2 & $25.09 \mathrm{a}$ & $29.44 \mathrm{a}$ & $30.00 \mathrm{a}$ & $21.69 \mathrm{a}$ \\
V1J3 & $29.79 \mathrm{c}$ & $30.00 \mathrm{~b}$ & $31.75 \mathrm{a}$ & $23.32 \mathrm{~b}$ \\
V2J1 & $23.49 \mathrm{a}$ & $30.00 \mathrm{~b}$ & $30.72 \mathrm{a}$ & $25.84 \mathrm{~b}$ \\
V2J2 & $26.14 \mathrm{a}$ & $30.00 \mathrm{~b}$ & $33.66 \mathrm{a}$ & $29.97 \mathrm{c}$ \\
V2J3 & $25.03 \mathrm{a}$ & $29.25 \mathrm{a}$ & $31.38 \mathrm{a}$ & $17.91 \mathrm{a}$ \\
V3J1 & $27.92 \mathrm{~b}$ & $21.90 \mathrm{a}$ & $31.38 \mathrm{a}$ & $17.90 \mathrm{a}$ \\
V3J2 & $28.65 \mathrm{~b}$ & $25.34 \mathrm{a}$ & $31.42 \mathrm{a}$ & $16.35 \mathrm{a}$ \\
V3J3 & $26.01 \mathrm{a}$ & $22.21 \mathrm{a}$ & $31.75 \mathrm{a}$ & $17.08 \mathrm{a}$ \\
\hline
\end{tabular}

Keterangan : Purata intensitas kerusakan hama yang diikuti huruf yang sama berarti tidak berbeda nyata pada taraf $5 \%$ uji BNT.

Tabel 2 menunjukkan bahwa pada varietas Grobogan dengan jarak tanam $30 \mathrm{~cm}$ x $40 \mathrm{~cm}$ (V1J3) menghasilkan intensitas serangan hama belalang tertingi dengan rata-rata $29,79 \%$ berpengaruh sangat 
nyata terhadap jarak tanam $30 \mathrm{~cm}$ x $20 \mathrm{~cm}(\mathrm{~V} 1 \mathrm{~J} 1)$ yaitu dengan rata-rata 25, 09\% dan pada jarak tanam $30 \mathrm{~cm}$ x $30 \mathrm{~cm}(\mathrm{~V} 1 \mathrm{~J} 2)$ rata-rata 25,09\%. Pada varietas Anjasmoro menunjukkan bahwa dengan menggunakan jarak tanam $30 \mathrm{~cm}$ x $30 \mathrm{~cm}$ (V2J2) menghasilkan intensitas serangan hama belalang tertingi yaitu dengan rata-rata $26,14 \%$. Namun tidak berpengaruh nyata terhadap jarak tanam $30 \mathrm{~cm} \mathrm{x}$ $20 \mathrm{~cm}(\mathrm{~V} 2 \mathrm{~J} 1)$ dengan rata-rata $23,49 \%$, dan pada jarak tanam $30 \mathrm{~cm} \mathrm{x} 40 \mathrm{~cm}(\mathrm{~V} 2 \mathrm{~J} 3)$ rata-rata 25,03\%. Varietas kedelai hitam Malika menunjukkan bahwa (V3J2) menghasilkan intensitas serangan hama belalang tertingi yaitu rata-rata $28,65 \%$ berpengaruh nyata terhadap jarak tanam $30 \mathrm{~cm} \times 20 \mathrm{~cm}$ (V3J3) dengan rata-rata $26,01 \%$. Akan tetapi tidak berpengaruh nyata terhadap jarak tanam $30 \mathrm{~cm} \times 40 \mathrm{~cm}$ (V3J1) rata-rata $27,92 \%$.

Hama ulat daun ditemukan pada varietas Grobogan menggunakan jarak tanam $30 \mathrm{~cm}$ x $40 \mathrm{~cm}$ (V1J3) dengan rata-rata tertinggi $30 \%$ berpengaruh nyata terhadap jarak tanam $30 \mathrm{~cm} \times 20 \mathrm{~cm}$ (V1J1) rata-rata $29.55 \%$ dan pada jarak tanam $30 \mathrm{~cm}$ x $30 \mathrm{~cm}$ (V1J2) menghasilkan rata rata 29.44\%. Namun pada (V1J1) dan (V1J2) tidak ada interaksi yang nyata. Varietas kedelai Anjasmoro menunjukkan bahwa pada jarak tanam $30 \mathrm{~cm}$ x $20 \mathrm{~cm}$ (V2J1) dan pada jarak tanam $30 \mathrm{~cm}$ x $30 \mathrm{~cm}$ (V2J2) menghasilkan intensitas serangan hama ulat daun tertingi yaitu rata-rata $30 \%$ akan tetapi keduanya tidak berpengaruh nyata. Namun berpengaruh terhadap tanaman kedelai dengan jarak tanam $30 \mathrm{~cm} \mathrm{x}$ $40 \mathrm{~cm}$ (V2J3) dengan rata-rata 29,25\%. Tanaman kedelai varietas Malika dengan jarak tanam $30 \mathrm{~cm} \mathrm{x}$ $30 \mathrm{~cm}$ (V3J2) menghasilkan intensitas serangan hama tertinggi yaitu dengan rata-rata $25,34 \%$ akan tetapi tidak berpengaruh nyata terhadap jarak tanam $30 \mathrm{~cm}$ x $20 \mathrm{~cm}(\mathrm{~V} 3 \mathrm{~J} 1)$ rata-rata 22,90\% dan jarak tanam $30 \mathrm{~cm}$ x $40 \mathrm{~cm}$ dengan rata-rata $22,21 \%$.

Varietas Grobogan dengan jarak tanam $30 \mathrm{~cm}$ x $40 \mathrm{~cm}$ (V1J3) menghasilkan intensitas serangan hama ulat grayak tertingi yaitu rata-rata $31,73 \%$ akan tetapi tidak berpengaruh nyata terhadap jarak tanam $30 \mathrm{~cm}$ x $20 \mathrm{~cm}$ (V1J1) dengan rata-rata 31,49\% dan pada jarak tanam $30 \mathrm{~cm} \times$ $30 \mathrm{~cm}$ (V1J2) dengan rata-rata 30\%. Varietas Anjasmoro pada jarak tanam $30 \mathrm{~cm}$ x $30 \mathrm{~cm}$ (V2J2) menghasilkan intensitas serangan hama ulat grayak tertinggi yaitu dengan rata-rata $33,66 \%$ akan tetapi tidak berbeda nyata terhadap jarak tanam $30 \mathrm{~cm}$ x $20 \mathrm{~cm}$ (V2J1) rata-rata 30,72\% dan pada jarak tanam $30 \mathrm{~cm}$ x $40 \mathrm{~cm}(\mathrm{~V} 2 \mathrm{~J} 3)$ dengan rata-rata 31,38\%. Varietas Malika dengan jarak tanam $30 \mathrm{~cm} \mathrm{x}$ $40 \mathrm{~cm}$ (V3J3) menghasilkan intensitas serangan hama tertinggi yaitu dengan rata-rata $31,75 \%$ akan tetapi tidak berbeda nyata terhadap jarak tanam $30 \mathrm{~cm}$ x $20 \mathrm{~cm}(\mathrm{~V} 3 \mathrm{~J} 1)$ dengan rata-rata 31,38\% dan jarak tanam $30 \mathrm{~cm} \times 30 \mathrm{~cm}$ (V2J3) dengan rata-rata $31,42 \%$.

Tanaman kedelai varietas Grobogan pada jarak tanam $30 \mathrm{~cm}$ x $40 \mathrm{~cm}$ (V1J3) menghasilkan intensitas serangan hama penggerek polong tertinggi yaitu dengan rata-rata $23,32 \%$ berbeda nyata terhadap jarak tanam $30 \mathrm{~cm}$ x $20 \mathrm{~cm}(\mathrm{~V} 1 \mathrm{~J} 1)$ rata-rata 18,11\% dan jarak tanam $30 \mathrm{~cm}$ x $30 \mathrm{~cm}(\mathrm{~V} 1 \mathrm{~J} 2)$ rata-rata 11,69\%. Untuk varietas Anjasmoro pada jarak tanam $30 \mathrm{~cm}$ x $30 \mathrm{~cm}$ (V2J2) memiliki intensitas serangan hama penggerek polong tertinggi dengan rata-rata $29,97 \%$ berbeda sangat nyata terhadap jarak tanam $30 \mathrm{~cm}$ x $40 \mathrm{~cm}$ (V2J3) dengan rata-rata 17,91\%. Namun berbeda nyata dengan jarak tanam $30 \mathrm{~cm}$ x $20 \mathrm{~cm}(\mathrm{~V} 2 \mathrm{~J} 1)$ rata-rata $25,84 \%$.

Tabel 3. Hasil Panen

\begin{tabular}{cccccc}
\hline Perlakuan & Jumlah Polong & Berat Polong & Jumlah Biji & Berat Biji & Berat 100 Biji \\
\hline V1J1 & $64.07 \mathrm{a}$ & $39.73 \mathrm{a}$ & $96.93 \mathrm{a}$ & $12.27 \mathrm{a}$ & $13.38 \mathrm{a}$ \\
V1J2 & $70.42 \mathrm{a}$ & $36.86 \mathrm{a}$ & $90.50 \mathrm{a}$ & $11.76 \mathrm{a}$ & $13.60 \mathrm{a}$ \\
V1J3 & $88.00 \mathrm{~b}$ & $60.11 \mathrm{~b}$ & $143.56 \mathrm{c}$ & $16.95 \mathrm{~b}$ & $12.10 \mathrm{a}$ \\
V2J1 & $48.2 \mathrm{a}$ & $20.34 \mathrm{a}$ & $60.33 \mathrm{a}$ & $6.85 \mathrm{a}$ & $11.89 \mathrm{a}$ \\
V2J2 & $54.83 \mathrm{a}$ & $29.45 \mathrm{a}$ & $95.00 \mathrm{~b}$ & $9.75 \mathrm{a}$ & $10.95 \mathrm{a}$ \\
V2J3 & $43.00 \mathrm{a}$ & $23.53 \mathrm{a}$ & $68.33 \mathrm{a}$ & $7.19 \mathrm{a}$ & $11.69 \mathrm{a}$ \\
V3J1 & $51.93 \mathrm{a}$ & $20.72 \mathrm{a}$ & $98.53 \mathrm{a}$ & $6.54 \mathrm{a}$ & $7.00 \mathrm{a}$ \\
V3J2 & $51.33 \mathrm{a}$ & $19.20 \mathrm{a}$ & $86.33 \mathrm{a}$ & $6.08 \mathrm{a}$ & $6.00 \mathrm{a}$ \\
V3J3 & $63.33 \mathrm{a}$ & $23.30 \mathrm{a}$ & $104.67 \mathrm{a}$ & $6.19 \mathrm{a}$ & $6.67 \mathrm{a}$ \\
\hline
\end{tabular}

Keterangan : Purata hasil panen yang diikuti huruf sama berarti tidak nyata pada taraf 5\% uji BNT. 
Tabel 3 menunjukkan varietas Grobogan pada jarak tanam $30 \mathrm{~cm} \mathrm{x} 40 \mathrm{~cm}$ (V1J3) menghasilkan jumlah polong tertingi yaitu dengan rata-rata 88.00 buah/tanaman berbeda nyata terhadap jarak tanam $30 \mathrm{~cm}$ x $20 \mathrm{~cm}(\mathrm{~V} 1 \mathrm{~J} 1)$ dengan rata-rata 64.07 buah/tanaman dan pada jarak tanam $30 \mathrm{~cm} \times 30 \mathrm{~cm}$ (V1J2 ) yaitu dengan rata-rata 70.42 buah/tanaman.

Varietas Grobogan jarak tanam $30 \mathrm{~cm} \times 40 \mathrm{~cm}$ (V1J3 ) menghasilkan berat polong tertingi yaitu dengan rata-rata $60.11 \mathrm{gram} / \mathrm{m}^{2}$ berbeda nyata terhadap jarak tanam $30 \mathrm{~cm}$ x $20 \mathrm{~cm}$ ( V1J1) dengan rata-rata $39,73 \mathrm{gram} / \mathrm{m}^{2}$ dan pada jarak tanam $30 \mathrm{~cm}$ x $30 \mathrm{~cm}$ ( V1J2 ) $36,86 \mathrm{gram} / \mathrm{m}^{2}$. Hal ini senada dengan hasil penelitian (Srihartanto dkk. 2012), penggunaan jarak tanam yang diperlebar memberikan hasil terbaik dibandingkan dengan jarak tanam lainnya. Jarak tanam yang terlalu rapat berakibat adanya kompetisi atau persaingan dalam mendapatkan unsur hara, cahaya atau sinar matahari dan air.

Pada varietas Grobogan dengan menggunakan jarak tanam $30 \mathrm{~cm} \times 40 \mathrm{~cm}$ (V1J3) menghasilkan jumlah biji tertingi yaitu dengan rata-rata 143,56 biji sangat berbeda nyata terhadap jarak tanam $30 \mathrm{~cm}$ x $20 \mathrm{~cm}$ (V1J1) 96.93 biji dan pada jarak tanam $30 \mathrm{~cm}$ x $30 \mathrm{~cm}$ (V1J2) yaitu dengan rata-rata 90.50 biji. Sedangkan (V1J1) dan (V1J2) tidak berpengaruh nyata. Hasil penelitian (Hakim, 2014) dari dua belas varietas kedelai, varietas Grobogan masuk kategori tiga varietas terbaik yang dievaluasi terdapat keragaman penampilan hasil biji antar genotype.

Pada varietas Grobogan pada jarak tanam $30 \mathrm{~cm}$ x $40 \mathrm{~cm}$ (V1J3) menghasilkan berat biji tertingi yaitu dengan rata-rata $16.95 \mathrm{gram} / \mathrm{m}^{2}$ berbeda nyata terhadap jarak tanam $30 \mathrm{~cm}$ x $20 \mathrm{~cm}$ ( V1J1) dengan rata-rata $12.27 \mathrm{gram} / \mathrm{m}^{2}$ dan pada jarak tanam $30 \mathrm{~cm}$ x $30 \mathrm{~cm}$ ( V1J2 ) yaitu dengan ratarata $11.76 \mathrm{gram} / \mathrm{m}^{2}$. Hal ini didukung oleh pendapat Kartasapoetra. (1985) bahwa tanaman dengan jarak tanam yang renggang mampu melakukan fotosintesis secara maksimal, sehingga fotosintat yang dihasilkan optimal dan pembentukan buah wose juga optimal.

Varietas Grobogan dengan jarak tanam $30 \mathrm{~cm}$ x $30 \mathrm{~cm}$ (V1J2) menghasilkan berat 100 biji tertingi yaitu dengan rata-rata $13.60 \mathrm{gram} / \mathrm{m}^{2}$ namun tidak berbeda nyata terhadap jarak tanam $30 \mathrm{~cm} \mathrm{x}$ $20 \mathrm{~cm}$ ( V1J1) dengan rata-rata $13.38 \mathrm{gram} / \mathrm{m}^{2}$ dan pada jarak tanam $30 \mathrm{~cm} \times 30 \mathrm{~cm}$ (V1J2) 12.10 gram $/ \mathrm{m}^{2}$. Hasil penelitian Abady et al. (2013) melaporkan indeks panen berpengaruh langsung secara nyata terhadap hasil biji kedelai. Potensi hasil yang tinggi dapat terjadi pada genotype yang mempunyai indeks panen yan tinggi juga.

\section{KESIMPULAN}

Berdasarkan hasil dan pembahasan maka dapat disimpulkan sebagai berikut :

1. Hama yang di temukan pada saat penelitian yaitu hama belalang hijau muncul pada umur 5 MST (Minggu Setelah Tanam) dengan intensitas serangan tertinggi 29,79\% pada perlakuan varietas Grobogan dengan jarak tanam $30 \mathrm{~cm}$ x $40 \mathrm{~cm}(\mathrm{~V} 1 \mathrm{~J} 3)$. Hama ulat daun muncul pada umur 7 MST dengan intensitas serangan tertinggi $30 \%$ pada perlakuan varietas Grobogan dengan menggunakan jarak tanam $30 \mathrm{~cm}$ x $40 \mathrm{~cm}$ (V1J3), varietas Anjasmoro dengan jarak tanam $30 \mathrm{~cm}$ x $20 \mathrm{~cm}$ (V2J1) dengan intensitas 30\%, dan (V2J2) varietas Anjasmoro menggunakan jarak tanam $30 \mathrm{~cm} \mathrm{x} 40 \mathrm{~cm}$ dengan rata-rata 30\%. Hama ulat grayak muncul pada umur 9 MST dengan intensitas serangan tertinggi 33,66\% pada perlakuan varietas Malika jarak tanam $30 \mathrm{~cm}$ x $30 \mathrm{~cm}$ (V2J2). Hama penggerek polong muncul pada umur 10 MST dengan intensitas serangan tertinggi 29,97\% pada perlakuan varietas Anjasmoro jarak tanam $30 \mathrm{~cm}$ x $30 \mathrm{~cm}$ ( V2J2 ).

2. Hasil panen terbaik terdapat pada varietas Grobogan dengan jarak tanam $30 \mathrm{~cm} \mathrm{x} 40 \mathrm{~cm}(\mathrm{~V} 1 \mathrm{~J} 3)$ menghasilkan jumlah polong tertinggi dengan rata-rata 88 biji, berat polong tertinggi dengan ratarata $60,11 \mathrm{gram} / \mathrm{m}^{2}$, jumlah biji tertinggi pada dengan rata-rata 143,56 biji dan berat biji tertinggi dengan rata-rata $16,95 \mathrm{gram} / \mathrm{m}^{2}$.

3. Varietas Anjasmoro dengan jarak tanam $30 \mathrm{~cm}$ x $40 \mathrm{~cm}$ menghasilkan tingkat serangan hamanya tinggi dan dapat memberikan hasil yang kurang optimal dibandingkan dengan varietas Grobogan. 


\section{DAFTAR PUSTAKA}

Abady et al. 2013. Heritability and path coefficient analysis in Soybeanbean (Glycine max .L. Merrill) genotipes. Jurnal of Environmental Science and Water Resources 2 (8) : 270-276.

Adisarwanto, T. 2006. Pengaruh Varietas dan Jarak Tanam Terhadap Pertumbuhan Kedelai. Di www.jurnal.unsyiah.ac.id. Diakses pada 29, Desember 2018.

Cahyadi. 2009. Kedelai Khasiat dan Teknologi. Jakarta: Bumi Aksara.

Hakim. 2014. Komponen Hasil dan Karakter Morfologi Penentu Hasil Kedelai pada Lahan Sawah Tadah Hujan. Bogor: Pusat Penelitian dan Pengembangan Tanaman Pangan.

Kartasapoetro. 1985. The Effect of Some Varieties and Spacing on Growth of Soybeanben. Banda Aceh: Jurnal Agrista Vol. 1b No.1.

Susanto. N. Nugrahaeni. 2016. Pengenalan dan Karakteristik Varietas Unggul Kedelai. Di balitkabi.litbang.pertanian.go.id Diakses Pada 7 Januari 2019.

Srihartanto dkk. 2012. Produktivitas Kedelai Dengan Berbagai Jarak Tanam Di Yogyakarta. Di balitkabi.litbang.pertanian.go.id Diakses Pada 16 Januari 2019.

Untung, K. 2013. Pengantar Pengelolaan Hama Terpadu (Edisi Kedua). Yogyakarta: Gadjah Mada University Press. Telah dicetak 5 kali. 